\title{
New chapter of Journal of the European Optical Society Rapid Publications
}

\author{
Kai-Erik Peiponen
}

Journal of the European Optical Society Rapid Publications (JEOS: RP) started to publish in 2006 scientific articles in the fields of photonics \& optics. JEOS: RP has started from $1^{\text {st }}$ May, 2016 a new chapter, namely SpringerOpen is now our publishing partner. This will be a new beginning in the sense that we work with a professional publishing partner that has a long experience in publishing scientific journals in variety of scientific fields. The new partner will be an important asset regarding the manuscript processing and publication of accepted articles in a timely manner, and all process phases are assisted by skillful and experienced persons of SpringerOpen who are working in the editorial office of JEOS: RP. The same high scientific standard as before will be our guideline for acceptance of manuscripts in the fields of photonics\& optics for publication. We continue publication of Rapid Publications and occasionally also review articles and critical reviews. I hope that JEOS: RP's collaboration with SpringerOpen will be a good start to provide a nice European option for publishing interesting articles on the theory and applications of photonics \& optics. Furthermore, I hope that we can offer a dynamic publication forum both in classical and also in new emerging fields that are devoted to, or involve photonics \& optics.

Editor-in-Chief

Kai-Erik Peiponen

Received: 12 May 2016 Accepted: 13 May 2016

Published online: 23 June 2016

Correspondence: kai.peiponen@joensuu.fi

Department of Physics and Mathematics, Institute of Photonics, University of Eastern Finland, Joensuu, Finland

\section{Submit your manuscript to a SpringerOpen ${ }^{\odot}$ journal and benefit from:}

- Convenient online submission

Rigorous peer review

- Immediate publication on acceptance

- Open access: articles freely available online

- High visibility within the field

Retaining the copyright to your article

Submit your next manuscript at $>$ springeropen.com 